\title{
PENERAPAN METODE HOUGH LINE TRANSFORM UNTUK MENDETEKSI PINTU RUANGAN MENGGUNAKAN KAMERA
}

\author{
Syahri Muharom \\ Jurusan Teknik Elektro Institut Teknologi Adhi Tama Surabaya \\ Jl. Arief Rachman Hakim, Klampis Ngasem, Sukolilo, Surabaya \\ syahrimuharom18@gmail.com
}

\begin{abstract}
The camera is often used to identify an object in the field of view of the camera. The door is one of the most important parts of a room, where to access entry of a person in the room, in this study camera used to detect the presence of the door of room. The process for detecting the door is by the identification of the characteristics of the door of room, the image of door captured by camera and image converted into gray, with edge detection image convert be binary form, and hough line transform to detecting of door characteristic. From the results of image processing using the hough line transform, image be line pattern at the frame of door, the lines is used as a parameter in detecting the door of room. The system can detect the door with an average value of $81.3 \%$, with luminance value of less than 120 and more than 350, the level of system accuracy of $73.3 \%$, and the luminance value of 224-230, the system accuracy rate of $93.3 \%$. It can be concluded that the luminance value greatly affect the detection door of the room, and the luminance value of 120-349 with the success rate of 80-93.3\%.
\end{abstract}

Keyword: Camera, Door of the Room, Hough lineTransform

\begin{abstract}
ABSTRAK
Kamera sering digunakan untuk mengenali suatu benda dalam bidang pandang kamera. Pintu adalah salah satu bagian terpenting dari suatu ruangan, dimana pintu adalah akses keluar dam masuknya seseorang dalam ruangan tersebut. Dalam penelitian ini kamera difungsikan untuk mendeteksi keberadaan pintu sebuah ruangan. Proses untuk pendeteksian pintu adalah dengan pengenalan ciri-ciri dari pintu ruangan, citra pintu yang di capture kamera diubah menjadi citra gray, dengan edge detection citra menjadi bentuk biner, dan hough-transform. Dari hasil pengolahan citra menggunkan hough-transform, citra menjadi pola garis-garis pada bagian bingkai pintu, garis-garis inilah yang dijadikan parameter dalam mendeteksi pintu ruangan. Sistem dapat mendeteksi pintu dengan nilai rata-rata $81.3 \%$, dimana nilai luminasi sangat mempengaruhi pendeteksian pintu ruangan. Dengan nilai liminasi kurang dari 120 dan lebih dari 350, tingkat akurasi sistem sebesar 73.3\%, dan dengan nilai luminasi 224-230, tingkat akurasi sistem sebesar 93.3\%. Dapat disimpulkan bahwa nilai luminasi sangat mempengaruhi dalam pendeteksian pintu ruangan, dan dengan nilai luminasi sebesar 120-349 tingkat keberhasilan sebesar 80-93.3\%.
\end{abstract}

Kata Kunci: Kamera, Pintu Ruangan, Hough lineTransform

\section{PENDAHULUAN}

Kamera sering digunakan untuk melacak benda bergerak yang berada dalam bidang pandang mereka, ini menjelaskan desain dan pengembangan kamera yang digunakan di dalam sebuah robot. Pelacakan berbasis kamera yang dilakukan terus-menerus dapat menangkap obyek bergerak tanpa perlunya kalibrasi kamera. [1]. Robot mendapatkan gambar dari target dengan menggunakan kamera yang akan menjadi referensi robot. Robot bisa mendapatkan gambar resolusi tinggi secara real time.[2]

Pintu dan benda umum yang berada dalam lingkungan didalam ruangan, dapat di deteksi oleh sebuah robot dengan menggunakan sistem navigasi untuk memetakan bangunan. Paper ini menyajikan pendekatan baru untuk mendeteksi pintu di dalam ruangan yang berda pada lingkungan dengan menggunakan visi komputer. Pintu yang akan dicari dalam gambar yang telah diolah menjadi gray-level, kamera akan mendeteksi segmen yang membentuk kusen. Hough- 
Transform digunakan untuk mengekstrak segmen dalam gambar setelah menerapkan Canny detektor tepi.

Fitur seperti ukuran, arah, atau jarak antara segmen, sistem fuzzy digunakan oleh untuk menganalisis apakah hubungan antara mereka mengungkapkan keberadaan pintu. Sistem ini telah disetel menggunakan algoritma genetika untuk mencapai performa maksimal dalam mendeteksi pintu. Untuk itu, database besar gambar yang mengandung pintu dilihat dari sudut yang berbeda dan jarak telah dibuat. Metode ini terbukti dapat mendeteksi pintu dengan cukup cepat untuk digunakan dalam aplikasi secara langsung.[3]

\section{TINJAUAN PUSTAKA}

Pada kajian pustaka ini menunjukkan beberapa jurnal yang mendukung penelitian ini, dan juga sebagai perbandingan dalam mengerjakan penelitian ini.

\section{Deteksi Pintu Menggunakan Komputer Vision}

Pada penelitian yang dilakukan oleh "Rafael Munos-Salinas" menjelaskan tentang visual door detection. Pada bagian ini dijelaskan bagaimana proses deteksi pintu visual yang dilakukan. Pendekatan kami didasarkan pada deteksi segmen, gambar yang membentuk bagian dari bingkai pintu. Oleh karena itu, kita mencari segmen yang membentuk bingkai pintu. Ketika bingkai pintu ditangkap dalam sebuah gambar, dapat membentuk dua sisi dengan sekitarnya, ada tepi dibentuk oleh frame dan dinding. Di sisi lain ada tepi dibentuk oleh frame dan daunnya (jika warna mereka berbeda) atau kesenjangan pintu (jika terbuka). Oleh karena itu, berdasarkan pengalaman kami, kami telah mengidentifikasi dua kemungkinan kasus di mana kerangka pintu dapat dideteksi.

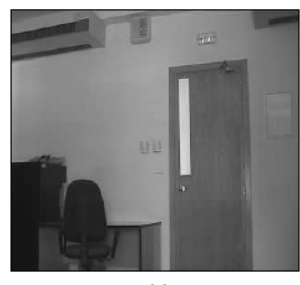

(a)

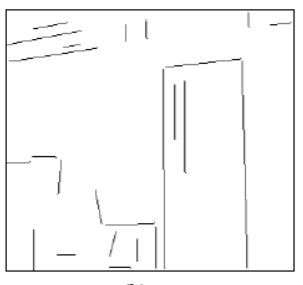

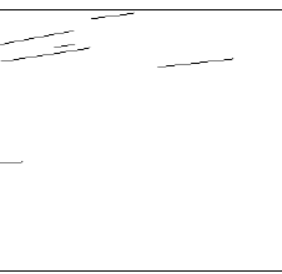

(c)

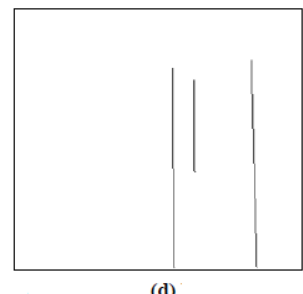

(d)

Gambar 1. Proses klasifikasi segments (a) Cita awal (b) Hasil extracted segments (c) Horozontal segments (d) Vertical segments

Kasus pertama, hanya satu dari pinggiran bingkai. Kasus ini telah secara resmi didefinisikan konsep sederhana frame (SF). Kasus kedua, kedua pinggiran bingkai. Kasus ini telah secara resmi didefinisikan oleh fuzzy konsep Bingkai ganda (DF). Kasus ideal yang segmen frame benar-benar vertical dan horisontal, itu hanya terjadi ketika kamera benar-benar di depan pintu dan selaras dengan lantai. Fuzzy Konsep Bingkai Sederhana digunakan untuk mewakili keunggulan dari bingkai pintu. Hal ini didefinisikan sebagai sepasang segmen vertikal yang tergabung dalam bagian atasnya ke segmen horisontal.[3]

\section{Deteksi Visual Pintu dengan Mengintegrasikan bentuk rupa dan ciri-ciri dari pintu}

Sebuah komponen penting dari interaksi manusia dan robot adalah kemampuan untuk mengaitkan konsep simantik dengan lokasi yang dihadapi dan juga objek. Fungsi ini sangat penting untuk navigasi visual dan pengenalan objek, fokus bahasan dalam jurnal ini mendetaksi pintu dengan menggunkan informasi fisual saja. Pintu yang sering ditemui dalam struktur buatan manusia dan lingkungan berfungsi sebagai transisi antara tempat yang berbeda.

Pada jurnal ini mengadopsi pendekatan probabilistik untuk mendeteksi pintu, dengan mendiskripsikan berbagai kemungkinan fitur untuk hipotesis pintu yang dihasilkan. Berbeda dengan sebelumnya model yang diusulkan menangkap kedua bentuk dan penampilan pintu, hal ini 
belajar dari beberapa contoh pelatihan, mengeksploitasi asumsi tambahan tentang struktur lingkungan dalam ruangan.
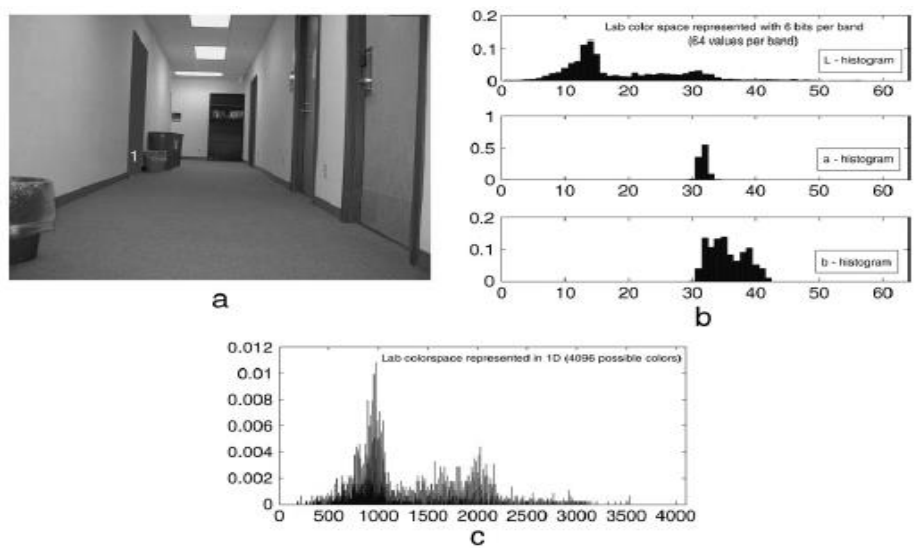

Gambar 2. (a) Contoh denah pintu (b) Marginal (c) Histogram dinormalisasi

Setelah itu menggambarkan proses generasi hipotesis dan beberapa pendekatan untuk mengevaluasi kemungkinan evaluasi yang dihasilkan. Pendekatan ini diuji pada berbagai contoh dalam ruangan lingkungan yang berbeda, ini menunjukkan kinerja yang baik asalkan sejauh pintu digambar cukup besar dan didukung oleh fitur pengukuiran.[4]

\section{Kamera Kinect}

Kamera yang digunakan pada robot adalah kamera microsoft kinect xbox 360. Kinect adalah perangkat input untuk mendeteksi gerakan yang diproduksi oleh Microsoft untuk Video Game XBOX 360 dan PC dengan sistem operasi windows. Dengan menggunakan kamera yang mirip dengan webcam memungkinkan untuk mengambil citra berwarna dengan format RGB. Resolusi yang dihasilkan citra RGB sebesat 640x480 pada kecepatan 30fps dan 1280x960 pada kecepatan $12 \mathrm{fps}$. Sistem ini nantinya akan di terapkan pada robot yang bergerak menggunakan persepsi visual berbasis kamera, sehingga sistem navigasi pada robot ini hanya menggunakan kamera sebagai sensornya [5]

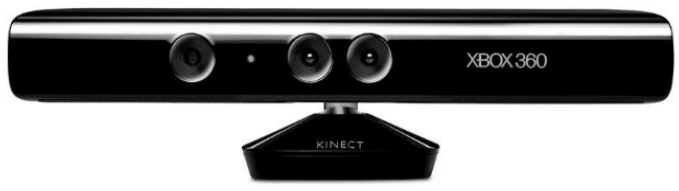

Gambar 3. Kamera Kinect

\section{Hough Line Transform}

Hough Transform pertama kali diperkenalkan oleh Paul Hough pada tahun 1962 untuk mendeteksi garis lurus. Hough line Transform adalah teknik transformasi citra yang dapat digunakan untuk mengisolasi atau dengan kata lain memperoleh fitur dari sebuah citra. Karena tujuan dari sebuah transformasi adalah mendapatkan suatu fitur yang lebih spesifik. 


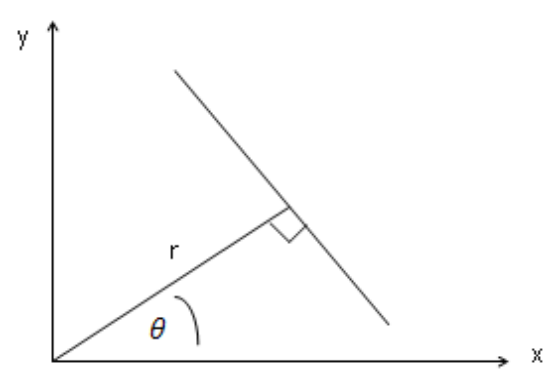

Gambar 4. Sudut pembentuk citra garis

Hough line Transform merupakan teknik yang paling umum digunakan untuk mendeteksi objek yang berbentuk kurva seperti garis, lingkaran, elips dan parabola. Keuntungan utama dari transformasi Hough adalah dapat mendeteksi sebuah tepian dengan celah pada batas fitur dan secara relatif tidak dipengaruhi oleh derau atau noise. Transformasi Hough memiliki beberapa perbedaan rumus yang diterapkan. Semuanya tergantung pada jenis objek yang dicari, misalnya untuk mencari objek garis digunakan fungsi garis seperti berikut ini:

$$
X \cos \theta+y \sin \theta=r
$$

Dengan $\mathrm{x}$ dan y merupakan titik koordinat yang menyusun objek garis tersebut, sedangkan teta adalah sudut yang dibentuk antara objek garis dengan sumbu $\mathrm{x}$, dan $\mathrm{r}$ merupakan jarak antara garis dengan titik pusat $(0,0)$. Untuk lebih jelasnya dapat diilustrasikan dengan menggunakan gambar 4 . Dalam proses transformasi lingkaran Hough, meliputi tiga bagian dasar. Bagian yang pertama adalah deteksi tepi. Tujuan deteksi tepi adalah untuk menurunkan jumlah titik dalam pencarian ruang bagi objek. Ketika titik tepi ditemukan oleh detektor tepi, algoritma transformasi Hough dikerjakan hanya pada titik tersebut. Untuk deteksi tepi, digunakan detektor tepi Canny, Roberts Cross, atau Sobel yang tujuannya memaksimalkan sinyal pada rasio derau dan lokalisasi serta meminimalisasi kesalahan pada deteksi tepi.[6]

\section{METODA}

Pada metode membahas tentang beberapa tahapan pembuatan sistem pendeteksian pintu sebuah ruangan menggunakan persepsi visual. Tahapan-tahapan tersebut meliputi penentuan lokasi dimana kamera melakukan proses pengenalan dari pintu ruangan. Dapat dilihat penempatan kamera pada bagian robot pada gambar 5 .

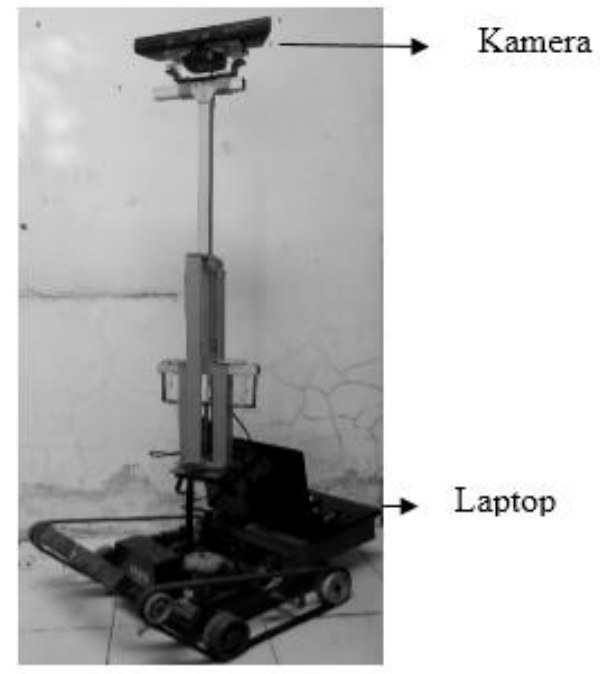

Gambar 5. Disain penempatan kamera pada robot 


\section{Parameter Pintu}

Pintu yang di deteksi harus memiliki parameter yang telah di tetapkan seperti terlihat pada gambar 6, untuk lebar dan tinggi pintu juga sangat berpengaruh pada pengambilan dan pemrosesan pengenlan pintu ruangan, ketika pintu terlalu besar maka kamera menganggap itu bukan sebuah pintu, begitu juga ketika pintu terlalu kecil. Ukuran pada pintu yang di deteksi memiliki lebar kurang lebih 1 meter dan tinggi kurang lebih 1.9 meter.

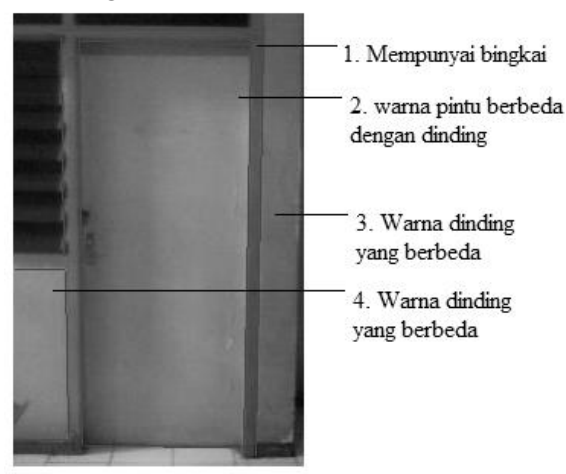

Gambar 6. Parameter pintu

\section{Tahap Pengenalan Pintu}

Sebelum melakukan pendeteksian keberadaan pintu ruangan, sistem terlebih dahulu harus mengenali bentuk dan ciri-ciri dari sebuah pintu. Proses ini dilakukan dengan menyiapkan template dari pintu yang dideteksi, template yang digunakan adalah bagian target area dari pintu yang digunakan. Template yang digunakan di tunjukkan pada gambar 6. Citra template yang masih dengan format RGB kemudian dikonversi menjadi citra grayscale. Dan pada gambar 7 adalah perubahan citra dari RBG menjadi grayscale.

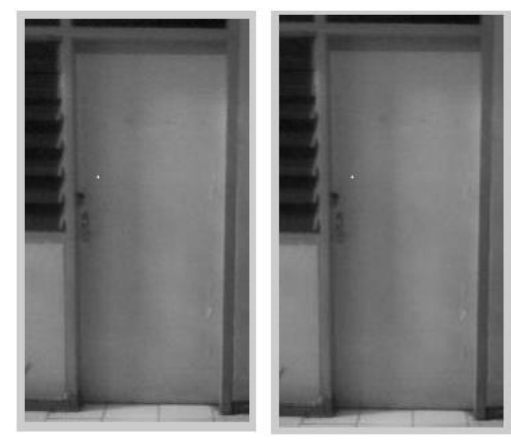

Gambar 1. Perubahan citra RGB menjadi grayscale

Perubahan citra dari RGB menjadi gray ini dilakukan untuk mempermudah pengolahan citra yang dilakukan selanjutnya. Proses pengolahan citra pendeteksian tepi menggunakan metode canny, dapat dilihat pada gambar 8 , hasil dari pemrosesan citra bingkai dari pintu dapat terlihat dengan jelas, dengan membandingkan citra dengan nilai yang sangat berbeda antar gelap dan terang 0 dan 255, proses pendeteksian tepi ini sangat membantu dalam penerapan hough transform. 


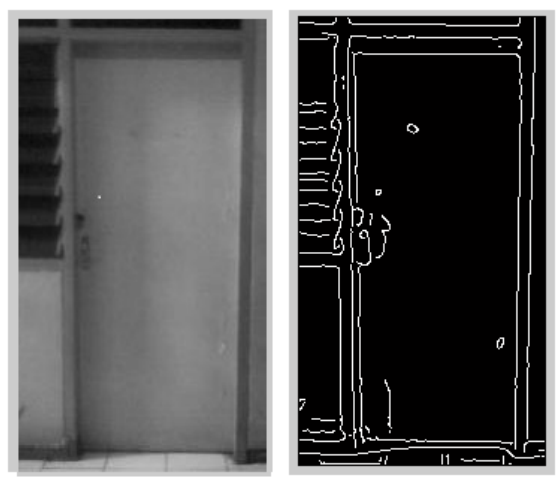

Gambar 2. Perubahan citra gray menjadi edge canny

\section{HASIL DAN PEMBAHASAN}

Pada bagian ini akan dibahas tentang beberapa proses pembuatan sistem pendeteksian pintu menggunakan persepsi visual. Pada bagian ini dibahas mengenai hasil pengujian sistem beserta analisa yang diperoleh dari data percobaan.

\section{Pengujian Pendeteksian Pintu}

Proses pendeteksian pintu ruangan dilakukan dengan parameter-parameter yang telah ditentukan sebelumnya. Pintu yang menjadi parameter ini memiliki fitur yang mirip dengan citra yang nantinya menjadi target pendeteksian pintu. Sistem tidak bisa mengani semua jenis pintu dikarenakan setiap pintu memiliki ciri-ciri yang berbeda.

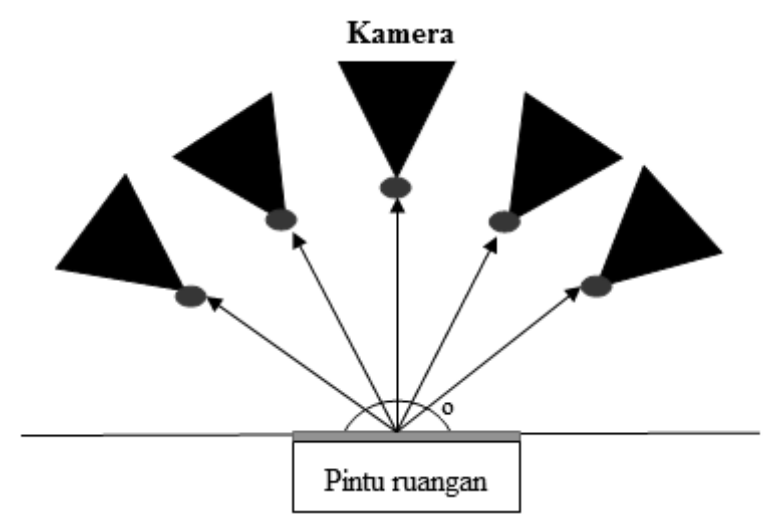

Gambar 9. Sudut kamera dalam mendeteksi pintu

Pada gambar 9 tampilan sudut kamera dalam mendeteksi pintu ruangan, percobaan yang dilakukan, dengan memindahkan kamera pada sudut yang telah di tetapkan, kemudian dilakukan pengambilan citra, citra di proses untuk mendapatkan karakteristik dari pintu, sudut yang sesuai untuk melaukan percobaan citra pintu adalah $90^{\circ}$. Sehingga citra pintu dapat terlihat semua bagianya saat di capture, seperti pada gambar 10 . 


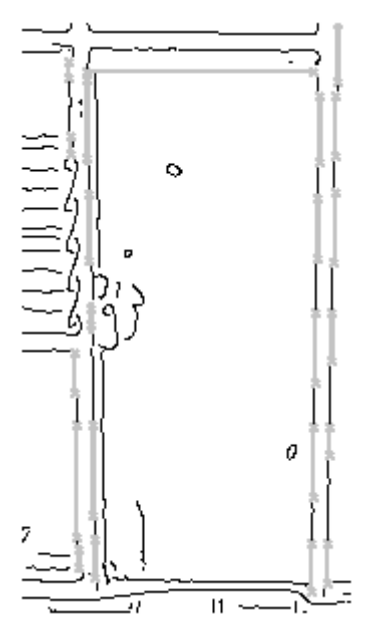

Gambar 10. Hasil capture kamera dan pemrosesan Hough line transform

Pada tabel 1 sudut robot dalam mendeteksi pintu ruangan menjelaskan bahwa, sudut terbaik untuk melakukan pendeteksian pintu adalah $90^{\circ}$. Hasil pendeteksian pintu pada sudut yang lain masih belum mencakup dari nilai parameter yang telah ditentukan, sehingga proses pencocokan citra pintu masih mengalami kegagalan.

Tabel.1 Sudut robot dalam mendeteksi pintu

\begin{tabular}{ccc}
\hline No & Sudut kamera robot $\left(^{\circ}\right)$ & Bagian yang terdeteksi \\
\hline 1 & 45 & Hanya separuh bingkai pintu \\
\hline 2 & 70 & Bingkai pintu \\
\hline 3 & 90 & Seluruh bingkai pintu terdeteksi \\
\hline 4 & 110 & Bingkai pintu \\
\hline 5 & 145 & Hanya separuh bingkai pintu \\
\hline
\end{tabular}

Pengujian selanjutnya dengan merubah nilai luminasi cahaya pada bagian pintu, hal ini di lakukan agar dapat melihat pada nilai luminasi berapa pintu dapat terdeteksi dengan baik. Hasil pengujian akurasi pendeteksian terhadap luminasi di tampilkan pada tabel 2, pengujian diawali dengan tingkat luminasi 75-78 dengan mengurangi pencahayaan pada pintu yang terdeteksi. Dari 15 sampel citra yang di ujikan, hanya 11 citra yang berhasil terdeteksi, pada tingat luminasi yang sangat rendah sistem memiliki tingkat akurasi yang rendah. Dengan niai luminasi yang rendah ciriciri pintu tidak dapat terlihat dengan jelas, hal ini menjadi suatu alasan pintu selit untuk dikenali oleh kamera.

Tabel.2 Hasil pengujian akurasi sistem terhadap perubahan luminasi

\begin{tabular}{ccccc}
\hline No & Luminasi (lux) & Sampel & Sampel Terdeteksi & Akurasi (\%) \\
\hline 1 & $75-78$ & 15 & 11 & 73.3 \\
\hline 2 & $120-124$ & 15 & 13 & 86.6 \\
\hline 3 & $224-230$ & 15 & 14 & 93.3 \\
\hline 4 & $342-349$ & 15 & 12 & 80 \\
\hline 5 & $390-398$ & 15 & 11 & 73.3 \\
\hline & Jumlah & 75 & 61 & 81.3 \\
\hline
\end{tabular}

Pada pengujian yang dilakukan selanjutnya, luminasi di ubah menjadi lebih tinggi pada nilai 120-124 lux, dari 15 sampel citra yang di ujikan, sistem dapat mendeteksi sebanyak 13 gambar. Pendeteksian pintu yang mempunyai tingkat akurasi tertinggi, pada nilai lux sebesar 224-230. Dari 15 sampel yang di ujikan sisitem dapat mendeteksi sebanyak 14 citra pintu, hal ini yang menjadi 
salah satu parameter keberhasilan dalam mendeteksi pintu ruangan. Dengan semakin tinggi nilai luminasi yang diberikan, akurasi sistem menjadi semakin menurun. Pada tingkat luminasi sebesar 342-349 lux, dari 15 sampel percobaan sistem dapat mendeteksi sebanyak 12 citra. Pada luminasi di atas 390 lux tingkat akurasi pendeteksian menjadi turun kembali, dari 15 sampel citra hanya 11 yang berhasil terdeteksi. Dengan nilai luminasi yang tinggi maka pintu semakin terlihat terang, semakin terang pencahayaan pada bagian pintu menyebabkan kamera tidak dapat mengenali atau mendeteksi ciri-ciri dari pintu ruangan.

\section{KESIMPULAN}

Kamera berhasil dalam mendeteksi keberadaan pintu ruangan, sistem dapat mendeteksi pintu dengan nilai rata-rata sebesar $81.3 \%$. Dalam mendeteksi pintu ruangan semakin rendah nilai liminasi pada pintu, menyebabkan pendeteksian pintu menjadi buruk dengan tingkat akurasi $73.3 \%$, dan semakin tinggi nilai luminasi maka pendeteksian pintu menjadi menurun tingkat akurasinya sebesar $73.3 \%$, dan dalam pendeteksian pintu ruangan yang mempunyai tingkat akurasi sebesar 93.3\% dengan nilai luminasi antara 224-230. Dapat disimpulkan bahwa nilai luminasi sangat mempengaruhi dalam pendeteksian sebuah pintu ruangan, dan dengan nilai luminasi sebesar 120349 tingkat keberhasilanya sebesar 80-93.3\%.

\section{DAFTAR PUSTAKA}

[1] Nazim Mir-Nasiri "Camera-based 3D Object Tracking and Following Mobile Robot" School of Engineering Swinburne University of Technology, 2006.

[2] Takafumi Sonoura "Person Following Robot with Vision-based and Sensor Fusion Tracking Algorithm " Corporate R\&D Center, Toshiba Corporatio,Japan, 2008.

[3] RAFAEL MUN OZ-SALINAS, dkk "Door-detection using computer vision and fuzzy logic" Department of Computer Science and Artificial Intelligence University of Granada, 2005.

[4] Dr Jharna Majumdar "Intelligent Vision System for Door Sensing Mobile Robot" Department of Research and Development Nirtte Meenakshi Institute of Technology, 2012.

[5] http://www.microsoft.com/en-us/kinectxbox360 (di akses pada 23/11/2016 jam $16.45 \mathrm{wib)}$

[6] Usman Ahmad, "Pengolahan Citra Digital \& Teknik Pemrogramannya", Edisi Pertama, Graha Ilmu, 2005 